$3{ }^{a}$ Hannah P. Sassi MS, $\mathrm{PhD}^{1^{*}}$, Kelly A. Reynolds MSPH, $\mathrm{PhD}^{2}$, Ian L. Pepper $\mathrm{PhD}^{1}$ and Charles

\section{Evaluation of Hospital-grade Disinfectants on Viral Deposition on Surfaces after Toilet}

\section{Flushing}

P. Gerba $\mathrm{PhD}^{1}$

4

\author{
P. Gerba PhD
}

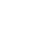

(1)

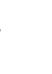

(1)

\author{
Affiliation: \\ ${ }^{1}$ Water and Energy Sustainable Technology Center, University of Arizona \\ 2959 W. Calle Agua Nueva \\ Tucson, AZ, USA, 85745
}

2

${ }^{2} \mathrm{Mel}$ and Enid Zuckerman College of Public Health, University of Arizona

1295 N. Martin Ave

Tucson, AZ, 85721

Hannah P. Sassi, MS, PhD; hannah.sassi@sydney.edu.au

T: +6128627 1375

\footnotetext{
${ }^{\text {a }}$ Present Address: The University of Sydney, School of Life and Environmental Science, Faculty of Science,

Biomedical Building C81, Level 4, The University of Sydney, NSW, 2006, Australia
} 


\section{Highlights}

24 - Droplet deposition of virus occurred on surfaces around the toilet when untreated,

25 infectious material was flushed.

26

27

- The highest concentration and incidence of surface contamination occurred nearest to the toilet bowl on the toilet seat and the toilet bowl rim.

28

29

- The deposition of droplets was significantly reduced $(p<0.05)$ when the waste was treated using a peracetic acid, quaternary ammonium, and chlorine-based disinfectant prior to flushing. 


\section{$31 \quad$ Abstract}

32 Background: Past studies have shown that infectious aerosols created during toilet flushing

33 results in surface contamination of the restroom. The goals of this study were to quantify viral

34 contamination of surfaces in restrooms after flushing and the impact of disinfectants added to the

35 toilet bowl prior to flushing on reducing surface contamination.

36 Methods: The degree of contamination of surfaces in the restroom was assessed with and

37 without the addition of coliphage MS-2 to the toilet bowl before flushing. The bowl water and

38 various surfaces in the restroom were subsequently tested for the presence of the virus.

39 Results: The toilet bowl rim, toilet seat top, and toilet seat underside were contaminated in all

40 trials without a disinfectant added to the bowl water before flushing. All disinfectants

41 significantly reduced concentrations on surfaces when the contact time was 15 min or greater.

42 Hydrogen peroxide resulted in very little reduction of virus in the toilet bowl $\left(<1 \log _{10}\right)$.

43 Peracetic acid and quaternary ammonium had the greatest log-reductions on virus in the organic

44 matter in the toilet.

45 Conclusions: Toilet flushing resulted in extensive contamination of surfaces within the

46 restroom. Addition of disinfectant to the toilet bowl prior to flushing reduced the level of

47 contamination in the bowl and fomites after flushing.

52 Keywords: Healthcare Associated Infections; Ebola virus; Aerosols; Fomite Transmission;

53 Disinfection 


\section{Introduction}

With the Ebola virus (EBV) outbreak in West Africa and the introduction of the disease

56 into the United States for the first time (in humans) in 2014, safe handling and effective

57 disinfection practices of potentially infectious waste have become especially important in the

58 healthcare setting ${ }^{1,2}$. It has been widely recognized for some time that infectious disease

59 transmission in healthcare environments can occur among patients and healthcare workers

$60(\mathrm{HCWs})^{3}$. The transmission dynamics and highly infectious nature of EBV are extremely

61 important factors to consider, in terms of protecting HCWs in all settings including outbreak

62 control centers and hospitals. It is well-established that the primary mode of transmission for

63 EBV is through direct contact with infected bodily fluids. The levels of virus in bodily fluids can

64 range from $10^{5.5}-10^{8} \mathrm{EBV}$ genome copies per $\mathrm{mL}^{4-6}$. This is assumed to be well over the

65 suspected median infectious dose of $<10$ viral particles. EBV is excreted not only in blood but

66 also in feces, urine, and vomit. When a patient is infected, they can release up to nine liters of

67 stool per day, discharging copious amounts of virus into the environment ${ }^{4}$.

Human pathogenic viruses shed in bodily fluids, such as norovirus, adenovirus, and

69 Torque teno virus are known to be aerosolized and deposited on hospital surfaces ${ }^{7,8}$. EBV

70 surrogates have recently been studied for aerosolization in waste disposal systems, specifically

71 toilets, aeration basins and sewer pipe convergences ${ }^{9}$. This exposure route of virus could result in

72 a heightened risk of environmental contact and transmission for HCWs. In 1979, a Sudanese

73 outbreak of EBV reported that HCWs were up to five times more likely to contract the virus than

74 those who did not practice patient care ${ }^{10}$. Fifteen years later, during the 1995 outbreak of EBV in

75 the Democratic Republic of the Congo, at least $32 \%$ of the infected individuals $(\mathrm{N}=296)$ were

76 healthcare workers ${ }^{10}$. Since these outbreaks, the Centers for Disease Control and Prevention 
77 (CDC) has released multiple guidance documents for hospitals for managing EBV patients and

78 suspected patients. In the most recent document, measures to control environmental spread were 79 provided and outlined ${ }^{11}$.

80 Use of an Environmental Protection Agency (EPA) registered disinfectant with claims

81 against non-enveloped viruses (noroviruses, enteroviruses, adenoviruses) was specified in

82 recommendations by the $\mathrm{CDC}$ as a method to reduce environmental fomite transmission of

$83 \mathrm{EBV}^{11}$. Fomite transmission of diseases has become one of the most recognized routes of

84 transmission in healthcare settings ${ }^{12}$. Because of this, environmental disinfection could be one of

85 the most important steps to containing an EBV outbreak in a hospital or healthcare setting. The

86 current standard for disposing of human waste materials is flushing into a sanitary sewer without

87 prior disinfection ${ }^{13}$. It is likely that $\mathrm{EBV}$, like other viruses, is being aerosolized during flushing

88 and subsequently settling onto surfaces. The resulting deposition of infectious droplets could

89 present an environmental transmission route for HCWs. Depending on the conditions, the virus

90 may be able to survive on surfaces between disinfections. EBV-Zaire was dried onto glass and

91 plastic surfaces, and was found to survive up to 50 days at lower temperatures $\left(+4^{\circ} \mathrm{C}\right)$. The

92 aerosolized virus was also detected after $90 \mathrm{~min}^{14}$.

93 Due to concern over the allowance of untreated infectious waste to be flushed into

94 sanitary sewers, the US Army Institute of Public Health released additional Standard Operating

95 Procedures for treatment of waste in toilets before flushing. Recommendations include adding

96 one cup of at least $5 \%$ or greater sodium hypochlorite, or low alcohol quaternary ammonium, to

97 toilet bowls, and allowing a 15-minute contact time before flushing ${ }^{15}$.

98 The main objective of this study was to evaluate the recommendations for disinfection of

99 waste before flushing on viral contamination of restroom surfaces. In addition to sodium 
100 hypochlorite and quaternary ammonium, hydrogen peroxide and peracetic acid were assessed as

101 disinfectants. The treatments were evaluated for the reduction of virus deposited onto surfaces

102 around the toilet after flushing. The second objective of this study was to compare the efficacies

103 of four disinfectants on reducing the viral concentration in the toilet bowl before flushing.

105 Methods and Materials

106

Inoculation and Sample Collection

107 In order to create a baseline for how the flushing of heavily contaminated organic waste 108 would deposit virus onto commonly touched surfaces around the toilet, $1000 \mathrm{~mL}$ volumes of 109 trypticase soy broth (TSB) (BD, Franklin Lakes, NJ, USA) were used to create a replicable and 110 uniform surrogate for human waste. Next, the TSB was inoculated with high titers $\left(\sim 1 \times 10^{12}\right)$ of 111 MS2 (ATCC 15597-B1), and added to a commercial valve-type toilet bowl containing $2.8 \mathrm{~L}$ of 112 water (American Standard, Piscataway, NJ, USA). The bacteriophage was propagated and 113 assayed as previously described by Sassi $e t a l^{16}$. After addition of the virus and broth, the toilet 114 was flushed, and surfaces around the toilet were sampled using sponge sticks moistened with 10 $115 \mathrm{~mL}$ of letheen broth (3M Brand, St. Paul, MN, USA) (Table 1). An area of $100 \mathrm{~cm}^{2}$ was sampled 116 for each site, except the toilet flush handle, which was $90 \mathrm{~cm}^{2}$. A succession of water samples 117 was also collected after one, two, and three flushes to determine residual virus in the bowl after 118 flushing. For these samples, $9 \mathrm{~mL}$ of water was collected from the toilet bowl and transferred to 119 a sterile $15 \mathrm{~mL}$ conical tube (BD, Franklin Lakes, NJ, USA) containing one $\mathrm{mL}$ of $10 \%$ sodium 120 thiosulfate (Sigma Aldrich, St. Louis, MO, USA) to neutralize any free chlorine in the toilet 121 water. To ensure there was no remaining MS2 on surfaces between trials, the surfaces were 122 cleaned with $70 \%$ ethanol, allowed to dry, and, subsequently sampled and assayed. 
124 Four hospital-grade disinfectants (Table 2) were tested in separate trials to assess the

125 efficacy of reducing the viral load aerosolized onto surfaces after flushing. One cup of each

126 disinfectant $(\simeq 236 \mathrm{ml})$ was added to the toilet bowl after the TSB and virus. Two contact times,

$127 \quad 15$ and $30 \mathrm{~min}$, were evaluated for each treatment to assess the reduction in deposition of virus

128 onto surfaces. Letheen broth (BD, Franklin Lakes, NJ, USA) and sodium thiosulfate were used to

129 neutralize the treatments. The same surfaces were sampled for all trials (Table 1). The reduction

130 of MS2 in the toilet bowl was quantified at three time points for each disinfectant. After the

131 addition of organic matter, virus, and disinfectant, $5 \mathrm{~mL}$ samples were collected from the toilet

132 bowl after 1,15 , and $30 \mathrm{~min}$. The samples were then transferred into sterile $15 \mathrm{~mL}$ conical tubes

133 containing either letheen broth or $10 \%$ sodium thiosulfate.

134 Sample Processing

135 Sponge stick samples were individually placed in a sterile plastic bag and eluted using 136 manual pressure application, as previously described in the literature ${ }^{16-19}$. The volume eluted 137 (approx. 4-6 mL) was recorded and used to calculate a total concentration per sampled surface 138 area. All samples (surfaces and water) were assayed using the double agar overlay method ${ }^{20}$ in 139 triplicate. Volumes of 1 or $0.1 \mathrm{~mL}$ were combined in melted top agar tubes $\left(50^{\circ} \mathrm{C}\right)$ with $0.5 \mathrm{~mL}$ 140 of host (E. coli ATCC 15597) before pouring onto TSA (BD, Franklin Lakes, NJ, USA). When 141 necessary, 10-fold serial dilutions of the samples were made using 0.01M PBS (pH 7.4) (Sigma 142 Aldrich, St. Louis, MO, USA). Plates were then incubated for $24 \mathrm{~h}$ at $37^{\circ} \mathrm{C}$ and viral plaques 143 enumerated. The concentration per $\mathrm{mL}$ of sample was determined for water samples collected 144 from the toilet bowl. The concentration per surface sample was calculated by determining the 145 average concentration per mL of eluent and multiplying by the total volume of eluent collected 
146 for the sample. This represents the concentration per $100 \mathrm{~cm}^{2}$ for each sample location except the

147 flush handle, which had a concentration per $90 \mathrm{~cm}^{2}$. The limit of detection for surface samples

148 was 1 plaque forming units $(\mathrm{PFU}) / 100 \mathrm{~cm}^{2}$. This was based off of the volume eluted from the

149 sponge stick and the volume assayed for each sample.

$150 \quad$ Statistical Analysis

151 The concentrations per $\mathrm{cm}^{2}$ on surfaces after use of disinfectant were compared to the

152 concentrations deposited onto surfaces without disinfectant using a paired, two-sided t-test.

153 Values were normalized using a log transformation. The log reductions observed after

154 disinfection of the toilet bowl at 1, 15, and 30 min contact times were compared using a

155 multivariate test of means for each disinfectant type. All statistical analyses were performed in

156 STATA 14 (Stata Corp., College Station, TX, USA).

\section{Results}

158 Droplet Deposition on Surfaces

The most heavily contaminated surfaces, on average, were the underside of the toilet seat,

160 the top side of the toilet seat, and the toilet bowl rim (Figure 1). Virus was detected 100\% of the

161 time after flushing at these three locations and had the highest concentrations of all surfaces. The

162 least contaminated surfaces after flushing were the flush handle, the wall behind the toilet (i.e.,

163 the back wall), and the toilet paper dispenser (Table 3 and 4). The flush handle and toilet paper

164 dispenser were the least frequently contaminated with virus being detected only $17 \%$ and $22 \%$ of

165 the time, respectively (Figure 1). Virus was only detected in one toilet bowl water sample after a

166 single flushing (1/54).

167 Comparison of Treatments 
The results of the paired t-tests showed that there was a significant reduction in

169 concentration from the baseline (without treatment) with all of the disinfectants, at the 15-minute

170 contact time $(p<0.05)$. With a 30-minute contact time, all disinfectants except hydrogen peroxide

171 showed a significant reduction when compared with no disinfectant (Table 4). When 30-minute

172 contact times were compared with 15-minute contact times, the only treatment that showed a

173 significant further reduction was chlorine bleach $(p=0.0174)$.

174 Comparison of Viral Reduction on Surfaces

175 Peracetic acid showed the greatest reduction of all treatments for all contact times. The 176 quaternary ammonium treatment produced a $1.99 \log _{10} \mathrm{PFU} / \mathrm{mL}$ reduction within one minute of

177 contact; however, the reduction only increased to $2.21 \log _{10}$ after a 30 minutes contact time.

178 Hydrogen peroxide exhibited the least reduction for all three contact times (Table 4). When these

179 values were analyzed using a multivariate test of means, the only statistically significant

180 differences in average reduction was seen between hydrogen peroxide and quaternary

181 ammonium $(p=0.0016)$, and between hydrogen peroxide and peracetic acid $(p=0.0147)$.

182 Peracetic acid and quaternary ammonium disinfection resulted in significantly reduced

183 concentrations compared to hydrogen peroxide.

184 Discussion

185 Surface Contamination after Flushing

186 Maximum deposition of virus after flushing occurred on locations closest to the source of

187 the virus (i.e., the toilet bowl). These sites were the toilet bowl rim, the seat top, and the seat

188 bottom. These surfaces have been noted in previous studies to be highly contaminated during

189 flushing events, as well as the floor beneath and next to the toilet ${ }^{21,22}$. Best et al. (2012) found

190 that flushing the toilet with the lid closed significantly reduced the amount of Clostridium 
191 difficile spores deposited on surfaces ${ }^{21}$. However, most commercial toilets do not have lids. If a 192 toilet does not have a lid, frequently contaminated surfaces after flushing should be disinfected

193 with a thorough hygiene protocol to reduce environmental contact with EBV and other infectious 194 agents excreted in bodily fluids in a healthcare setting. In contrast, the two least contaminated 195 surfaces were the flush handle and the toilet paper dispenser. These surfaces were the furthest 196 away from the source, suggesting that the droplets were not being ejected with enough force to 197 spread viable virus to more distant locations. It is presumed this is a result of the type of toilet, 198 and will likely vary depending on toilet, bowl volume and flush force. These surfaces should still 199 be targeted using surface disinfectants, however, due to their incidental and infrequent 200 contamination.

201 Treating infectious waste with any of the tested disinfectants other than hydrogen 202 peroxide showed significant reduction in the concentration of MS2 on surfaces, when compared 203 to the baseline with no disinfection. The reduction of viral contamination during flushing could 204 be an important control point in reducing environmental contact for HCWs, especially in an 205 outbreak setting. Pathogens in aerosols and suspended droplet nuclei, such as norovirus and $C$. 206 difficile, have been identified in air after flushing ${ }^{7,21}$. Escherichia coli in droplets has also been 207 captured on gauze over the toilet bowl during flushing. This study also showed that a lower 208 volume of water in the toilet bowl produced an average higher concentration of $E$. coli suspended 209 in droplets than a toilet with a greater volume ${ }^{23}$. The toilet tested in the present study had a 210 relatively low volume in the bowl during testing $(2.8 \mathrm{~L})$. When an inoculum of $10^{6}$ PFU was 211 used in the toilet, no virus could be detected on the surrounding surfaces (data not shown), which 212 demonstrates that the amount of virus being expelled during toilet flushing was less than the 213 assay detection limit $\left(1 \mathrm{PFU} / 100 \mathrm{~cm}^{2}\right)$. In this study, an average inoculum of $10^{12}$ was used, 
214 which resulted in continual contamination of the toilet seat and toilet bowl rim. Overall,

215 elimination and reduction of virus on surfaces minimizes the risk of exposure to staff through

216 contact with fomites.

217 Reduction of MS2 in the Toilet Bowl

218 The surrogate virus was never inactivated below the limit of detection for any of the

219 disinfectants studied (1 PFU/mL), which suggests that when present in high organic matter such

220 as in bodily fluids, viruses are much more difficult to inactivate. Thus, infectious virus were still

221 present in the toilet bowl during flushing. Of all the tested disinfectants, peracetic acid and

222 quaternary ammonium showed the greatest reduction for the one-minute contact time (2.26 and

$\left.2231.99 \log _{10}\right)$. In a previous study, EBV was completely reduced by sodium hypochlorite

224 concentrations of 5 and $10 \mathrm{mg} / \mathrm{L}$ in sterilized wastewater after 20 seconds. At $1 \mathrm{mg} / \mathrm{L}$, EBV was

225 reduced overall by $3.5 \log _{10}$ in 20 seconds $^{24}$. This contact time is significant because a higher-

226 than-average (30-60 seconds) contact time is likely to be unrealistic in a healthcare setting, given

227 the demands of staff availability ${ }^{25}$.

228 Recommendations

229 One of the major concerns with EBV infectious waste is the high concentration of viral

230 particles shed in bodily fluids $\left(10^{8} / \mathrm{mL}\right)^{4}$. In 2017 , recommendations on critical control points

231 and containment for EBV waste were outlined in a WHO publication. Latrine use, and

232 cleaning/disinfection were included as potential critical control points for environmental

233 contact $^{26}$. Results from this current study indicate that when high concentrations of virus are

234 present in the toilet bowl, detectable levels of virus on fomites in the restroom can occur in

235 concentrations of $10^{1}-10^{5}$, even with disinfection before flushing. Thus, even a small amount of

236 bodily fluid or fecal material can be expected to contaminate surfaces in the restroom. Treating 
237 waste in the toilet before flushing should be practiced in order to significantly reduce the

238 contamination of surfaces in the restroom. For situations where toilets are not readily available,

239 EBV waste should be treated before disposal, and disinfection of highly contaminated restroom

240 surfaces should be practiced regularly, and also in between flushing events. In order to

241 effectively reduce and/or eliminate contact between infectious particles and HCWs, controlling

242 contamination from the toilet is essential.

\section{Acknowledgements}

244 Funding and support for this research was provided by the National Science Foundation

245 Water Environmental Technology Center at the University of Arizona and the California

246 Association of Sanitation Agencies. 
248 1. Fauci AS. Ebola--underscoring the global disparities in health care resources. N Engl J

249 Med [Internet]. 2014;371(12):1084-6. Available from:

$250 \quad$ http://www.ncbi.nlm.nih.gov/pubmed/25119491

251 2. CDC. 2014 Ebola Outbreak in West Africa - Outbreak Distribution Map | Ebola

252 Hemorrhagic Fever | CDC [Internet]. 2016. Available from:

253 http://www.cdc.gov/vhf/ebola/outbreaks/2014-west-africa/distribution-map.html

254 3. Alexander JW. Nosocomial Infections. Curr Probl Surg. 1973;10(8):1-54.

255 4. Bibby K, Fischer RJ, Casson LW, Stachler E, Haas CN, Munster VJ. Persistence of Ebola 256 Virus in Sterilized Wastewater. Environ Sci Technol Lett. 2015;2(9):245-9.

257 5. Bausch DG, Towner JS, Dowell SF, Kaducu F, Lukwiya M, Sanchez A, et al. Assessment 258 of the Risk of Ebola Virus Transmission from Bodily Fluids and Fomites. J Infect Dis

259 [Internet]. 2007;196(s2):S142-7. Available from:

$260 \quad$ http://jid.oxfordjournals.org/lookup/doi/10.1086/520545

261 6. CDC. Transmission | Ebola Hemorrhagic Fever | CDC [Internet]. Centers for Disease 262 Control and Prevention. 2015. Available from:

263 http://www.cdc.gov/vhf/ebola/transmission/

264 7. Bonifait L, Charlebois R, Vimont A, Turgeon N, Veillette M, Longtin Y, et al. Detection 265 and Quantification of Airborne Norovirus during Outbreaks in Healthcare Facilities. Clin 266 Infect Dis. 2015;61(3):299-304.

267 8. Verani M, Bigazzi R, Carducci A. Viral contamination of aerosol and surfaces through 268 toilet use in health care and other settings. Am J Infect Control [Internet].

269 2014;42(7):758-62. Available from: http://dx.doi.org/10.1016/j.ajic.2014.03.026

270 9. Lin K, Marr LC. Aerosolization of Ebola Virus Surrogates in Wastewater Systems. 
Environ Sci Technol. 2017;51(5):2669-75.

272 10. Sepkowitz KA. Occupationally Acquired Infections in Health Care Workers: Part II. Ann

273

274

275

276

277

278

279

280

281

282

283

284

285

286

287

288

289

290

291

292

293

Intern Med [Internet]. 1996;125(11):917-28. Available from:

http://dx.doi.org/10.7326/0003-4819-125-11-199612010-00008

11. CDC. Interim Guidance for Environmental Infection Control in Hospitals for Ebola Virus | Ebola Hemorrhagic Fever | CDC [Internet]. Centers for Disease Control and Prevention. 2015. Available from: http://www.cdc.gov/vhf/ebola/hcp/environmental-infection-controlin-hospitals.html

12. Weber DJ, Rutala W a. Understanding and preventing transmission of healthcareassociated pathogens due to the contaminated hospital environment. Infect Control Hosp Epidemiol [Internet]. 2013 May [cited 2014 Feb 27];34(5):449-52. Available from: http://www.ncbi.nlm.nih.gov/pubmed/23571359

13. Bibby K, Casson LW, Stachler E, Haas CN. Ebola virus persistence in the environment: State of the knowledge and research needs. Environ Sci Technol Lett. 2015;2(1):2-6.

14. Piercy TJ, Smither SJ, Steward JA, Eastaugh L, Lever MS. The survival of filoviruses in liquids, on solid substrates and in a dynamic aerosol. J Appl Microbiol. 2010;109(5):1531-9.

15. Health USAI of P. EBOLA VIRUS DISEASE WASTE MANAGEMENT EBOLA VIRUS DISEASE WASTE MANAGEMENT. U.S. Army Institute of Public Health. 2014.

16. Sassi HP, Sifuentes LY, Koenig DW, Nichols E, Clark-Greuel J, Wong LF, et al. Control of the spread of viruses in a long-term care facility using hygiene protocols. Am J Infect Control [Internet]. 2015;43(7):702-6. Available from: 
http://www.ncbi.nlm.nih.gov/pubmed/25944726

295 17. Sexton JD, Reynolds KA. Exposure of emergency medical responders to methicillinresistant Staphylococcus aureus. Am J Infect Control [Internet]. 2010;38(5):368-73. Available from: http://dx.doi.org/10.1016/j.ajic.2010.01.004

18. Reynolds KA, Beamer PI, Plotkin KR, Sifuentes LY, Koenig DW, Gerba CP. The Healthy

21. Best EL, Sandoe JAT, Wilcox MH. Potential for aerosolization of Clostridium difficile

19. Sifuentes LY, Koenig DW, Phillips RL, Reynolds KA, Gerba CP. Use of Hygiene Protocols to Control the Spread of Viruses in a Hotel. Food Environ Virol. 2014;6(3):175Workplace Project: Reduced Viral Exposure in an Office Setting. Arch Environ Occup Health. 2015;8244(December):0.

20. Kropinski AM, Mazzocco A, Waddell TE, Johnson RP. Bacteriophages. Clokie MRJ, 81.

Kropinski AM, editors. 2009 [cited 2014 Jan 20];501:69-76. Available from: http://link.springer.com/10.1007/978-1-60327-164-6

23. Gerba CP, Wallis C, Melnick JL. Microbiological hazards of household toilets: droplet production and the fate of residual organisms. Appl Microbiol. 1975;30(2):229-37.

315 24. Bibby K, Fischer RJ, Casson LW, de Carvalho NA, Haas CN, Munster VJ. Disinfection of 
317 25. CDC. Guidelines Library | Infection Control | CDC [Internet]. Centers for Disease Control and Prevention. 2008. Available from:

319 https://www.cdc.gov/infectioncontrol/guidelines/index.html

320 26. Edmunds K, Bell DJ, Edmunds KL, Elrahman A, Bell DJ, Brainard J, et al.

321 Recommendations for dealing with waste contaminated with Ebola virus : a Hazard

322 Analysis of Critical Control Points approach Recommendations for dealing with waste

323 contaminated with Ebola virus : a Hazard Analysis of Critical Control Points approach.

324 Bull World Heal Organ. 2016;(June):424-32.

325 


\section{FIGURES 1}

327 Figure 1: Percent positive, by sample location $(n=18)$

328

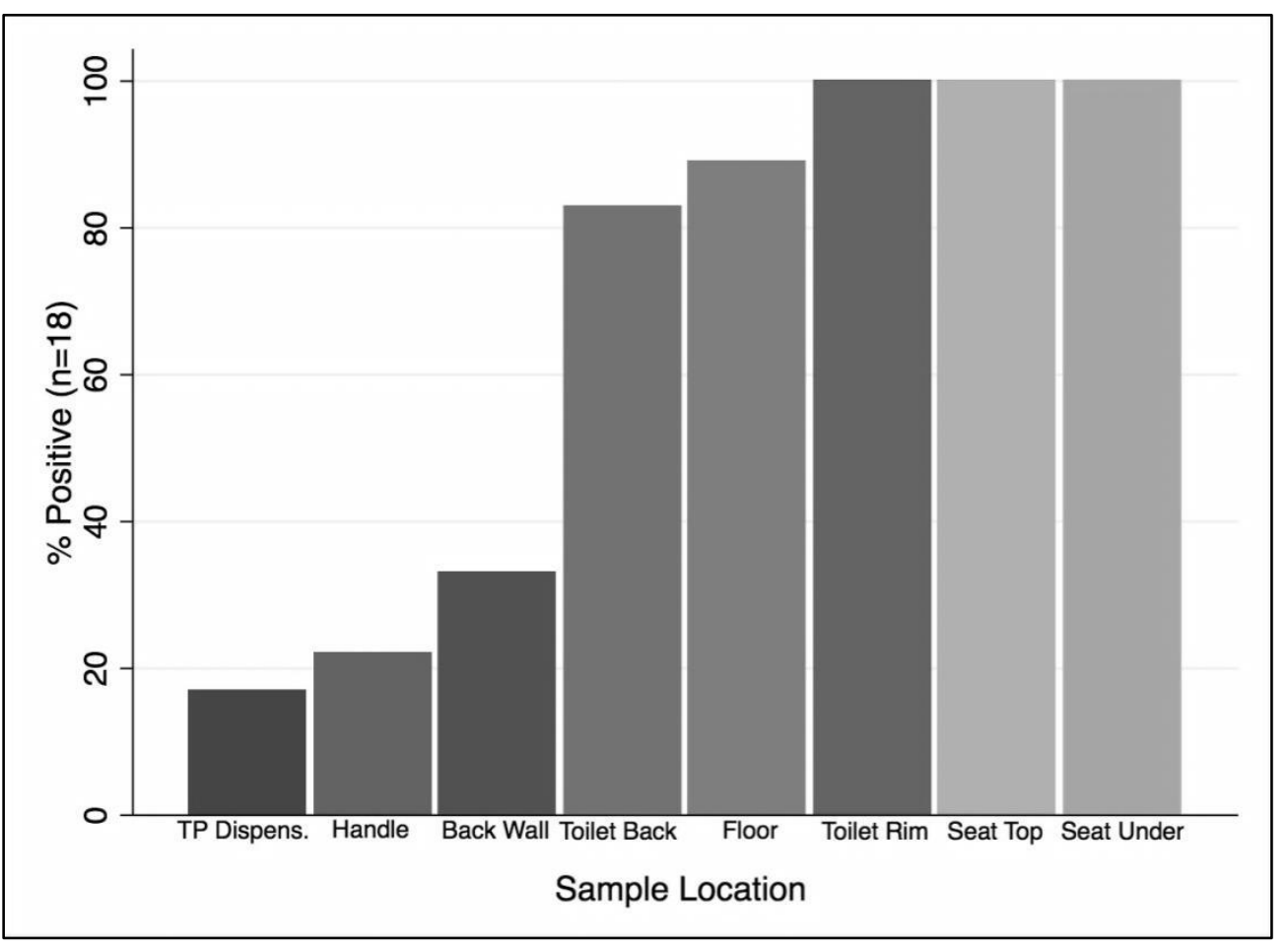

329 
331 Table 1: Restroom sample locations

\begin{tabular}{ccc} 
Sample & Location & Description \\
\hline 1 & Handle & Toilet flush handle \\
2 & Toilet Back & Back of toilet, mounting \\
3 & Back Wall & Wall where toilet is mounted \\
4 & Floor & Floor underneath toilet \\
6 & TP Holder & Toilet paper dispenser \\
7 & Toilet Bowl-In/Rim & Composite of toilet rim and under rim \\
8 & Toilet Seat Under & Top of the toilet seat
\end{tabular}

334 Table 2: List of treatments and percent active ingredient

\section{Disinfectants}

\begin{tabular}{ccc} 
Treatment Type & \% Active Ingredient & Manufacturer \\
\hline Bleach & 5-10: sodium hypochlorite & Clorox (Oakland, CA) \\
Hydrogen peroxide & 0.5-2: hydrogen peroxide & Clorox (Oakland, CA) \\
3-5: Alkyl dimethyl benzyl & \\
Quaternary ammonium & ammonium chloride & Clorox (Oakland, CA) \\
& & Decon (King of \\
Peracetic acid & $0.23:$ peracetic acid & Prussia, PA)
\end{tabular}


336 Table 3: Concentrations of virus detected on restroom surfaces after flushing for all trials $(N=18)$

Mean Concentrations, by Sample Site $(\mathrm{n}=18)$ per $100 \mathrm{~cm}^{2}$

$\begin{array}{ccc} & \text { Geometric Mean } \pm \text { SD }(\log 10 & \text { Arithmetic Mean } \pm \text { SD } \\ \text { Sample Site } & \text { PFU }) & (\text { PFU })\end{array}$

1-Flush Handle*

$1.65 \pm 0.91$

$2.65 \mathrm{E}+01 \pm 7.64 \mathrm{E}+01$

2-Toilet Back

$2.89 \pm 1.04$

$3.7 \mathrm{E}+03 \pm 7.3 \mathrm{E}+03$

3-Back Wall

$1.63 \pm 1.36$

$1.2 \mathrm{E}+03 \pm 5.3 \mathrm{E}+03$

4-Floor

$3.44 \pm 1.08$

$1.9 \mathrm{E}+04 \pm 4.2 \mathrm{E}+04$

5-Toilet Paper

Dispenser

$1.49 \pm 1.41$

$68.5 \pm 2.9 \mathrm{E}+02$

6-Toilet Bowl Rim

$3.88 \pm 1.59$

$3.1 \mathrm{E}+05 \pm 9.2 \mathrm{E}+05$

7-Toilet Seat Top

$4.21 \pm 1.26$

$3.4 \mathrm{E}+05 \pm 1.2 \mathrm{E}+06$

8-Toilet Seat

$4.22 \pm 1.26$

$2.5 \mathrm{E}+05 \pm 4.6 \mathrm{E}+05$

Underside

$*$ denotes $90 \mathrm{~cm}^{2}$ 
342 Table 4: Mean $\log _{10}$ reductions of MS2 per $m L$ by disinfectants in toilet bowl after indicated

343 exposure times $(N=3)$

\begin{tabular}{|cccc|}
\hline Treatment & 1 minute & 15 minute & 30 minute \\
\hline Chlorine Bleach & 0.48 & 1.4 & 2.83 \\
Hydrogen Peroxide & 0.01 & 0.03 & 0.06 \\
Quaternary Ammonium & 1.99 & 1.93 & 2.22 \\
Peracetic Acid & 2.26 & 3.37 & 3.43 \\
\hline
\end{tabular}

344

345 